\title{
Overproduction of Cholesterol and Fatty Acids Causes Massive Liver Enlargement in Transgenic Mice Expressing Truncated SREBP-1a
}

\author{
Hitoshi Shimano, ${ }^{\star}$ Jay D. Horton, ${ }^{\star}$ Robert E. Hammer, ${ }^{\ddagger}$ lichiro Shimomura, ${ }^{*}$ Michael S. Brown, ${ }^{\star}$ and Joseph L. Goldstein* \\ $*$ Departments of Molecular Genetics and ${ }^{\ddagger}$ Biochemistry, Howard Hughes Medical Institute, University of Texas Southwestern Medical \\ Center, Dallas, Texas 75235
}

\begin{abstract}
The $\mathrm{NH}_{2}$-terminal domain of sterol-regulatory element binding protein-1a (SREBP-1a) activates transcription of genes encoding enzymes of cholesterol and fatty acid biosynthesis in cultured cells. This domain is synthesized as part of a membrane-bound precursor that is attached to the nuclear envelope and endoplasmic reticulum. In sterol-depleted cells a two-step proteolytic process releases this $\mathrm{NH}_{2}$-terminal domain, which enters the nucleus and activates transcription. Proteolysis is suppressed by sterols, thereby suppressing transcription. In the current experiments we produce transgenic mice that overexpress a truncated version of human SREBP1a that includes the $\mathrm{NH}_{2}$-terminal domain but lacks the membrane attachment site. This protein enters the nucleus without a requirement for proteolysis, and therefore it cannot be down-regulated. Expression was driven by the phosphoenolpyruvate carboxykinase (PEPCK) promoter, which gives high level expression in liver. When placed on a low carbohydrate/high protein diet to induce the PEPCK promoter, the transgenic mice developed progressive and massive enlargement of the liver, owing to the engorgement of hepatocytes with cholesterol and triglycerides. The mRNAs encoding 3-hydroxy-3-methylglutaryl CoA (HMG CoA) synthase, HMG CoA reductase, squalene synthase, acetyl-CoA carboxylase, fatty acid synthase, and stearoyl-CoA desaturase-1 were all elevated markedly, as was the LDL receptor mRNA. The rates of cholesterol and fatty acid synthesis in liver were elevated 5- and 25-fold, respectively. Remarkably, plasma lipid levels were not elevated. The amount of white adipose tissue decreased progressively as the liver enlarged. These studies indicate that the $\mathrm{NH}_{2}$-terminal domain of SREBP-1a can produce major effects on lipid synthesis and storage in the liver. (J. Clin. Invest. 1996. 98:1575-1584.) Key words: SREBP • transgenic mice • cholesterol • fatty acids $\bullet$ LDL receptors
\end{abstract}

H. Shimano and J.D. Horton contributed equally to this work.

Address correspondence to Joseph L. Goldstein, M.D. or Michael S. Brown, M.D., Department of Molecular Genetics, University of Texas Southwestern Medical Center, 5323 Harry Hines Blvd., Dallas, Texas 75235. Phone: 214-648-2141; FAX: 214-648-8804.

Received for publication 20 June 1996 and accepted in revised form 25 July 1996.

J. Clin. Invest.

(C) The American Society for Clinical Investigation, Inc.

0021-9738/96/10/1575/10 \$2.00

Volume 98, Number 7, October 1996, 1575-1584

\section{Introduction}

Feedback regulation of cholesterol synthesis was observed in animal livers 45 years ago $(1,2)$, but a potential mechanism was uncovered only recently. When rodents and other experimental animals are fed a high cholesterol diet, the cholesterol accumulates in the liver, and this diminishes cholesterol production by decreasing the transcription of genes encoding several enzymes in the cholesterol biosynthetic pathway, including 3-hydroxy-3-methylglutaryl CoA (HMG CoA $)^{1}$ reductase $(3,4)$, HMG CoA synthase (5), farnesyl diphosphate synthase $(6)$, and squalene synthase $(7,8)$. In some species, such as hamsters (9) and monkeys (10), the gene for the low density lipoprotein (LDL) receptor is also repressed, thereby decreasing the hepatic uptake of cholesterol as well as its synthesis. A potential mechanism for this repression has recently been disclosed through studies in cultured cells (11).

In cultured cells feedback regulation of genes governing the synthesis and uptake of cholesterol is mediated by a pair of transcription factors designated sterol regulatory element binding proteins -1 and -2 (SREBP-1 and -2) (11-13). These proteins are composed of three segments: $(a)$ an $\mathrm{NH}_{2}$-terminal segment of $\sim 500$ amino acids that contains a basic-helix-loophelix-leucine zipper DNA binding domain and an acidic transcription activating domain; $(b)$ a middle segment composed of two membrane-spanning regions and a short lumenal loop that anchors the protein, hairpin-fashion, to membranes of the endoplasmic reticulum and nuclear envelope; and (c) a $\mathrm{COOH}-$ terminal segment of $\sim 500$ amino acids that performs a regulatory role. The proteins are oriented so that their $\mathrm{NH}_{2}$ and $\mathrm{COOH}$-terminal segments project into the cytoplasm (14).

The full-length membrane-bound form of each SREBP is called the precursor form. When cells are depleted of sterols, the $\mathrm{NH}_{2}$-terminal segment is cleaved from the precursor and released from the membrane in two steps $(11,15,16)$. First, a protease clips the SREBP at a site in the lumenal loop, thereby destroying the covalent link between the two membrane-spanning regions. This permits a second proteolytic cleavage to occur within the first transmembrane region, releasing the $\mathrm{NH}_{2}$ terminal segment so that it can enter the nucleus and activate transcription. This $\mathrm{NH}_{2}$ - terminal segment is called the mature form of SREBP. When sterols accumulate in cells, the first cleavage is abolished, and this precludes the second cleavage. As a result, the SREBPs remain in the membrane-bound precursor form, and transcription of the target genes declines.

Inasmuch as the SREBPs are normally regulated by controlled release from membranes, it is possible to bypass the regu-

1. Abbreviations used in this paper: GAPDH, glyceraldehyde-3-phosphate dehydrogenase; HMG CoA, 3-hydroxy-3-methylglutaryl CoA; PEPCK, phosphoenolpyruvate carboxykinase. 
latory step by producing truncated versions of SREBPs that terminate prior to the membrane attachment segment. These socalled "dominant positive" forms of SREBPs go directly to the nucleus and activate transcription without any requirement for proteolysis. Hence, they are immune to down-regulation (17-19).

The most well-understood target genes for the SREBPs encode HMG CoA synthase, an early enzyme in the cholesterol biosynthetic pathway, and the LDL receptor, which supplies cholesterol via receptor-mediated endocytosis (11-13). The 5' flanking regions of these genes contain a 10-bp element designated SRE-1 (20) that binds SREBPs $(12,13)$. Other genes are activated by overexpression of SREBPs, including the genes encoding farnesyl diphosphate synthase (21) and squalene synthase (22). Studies with artificial reporter genes containing the HMG CoA reductase promoter have failed to show high-level activation by co-expressed SREBPs $(12,13,23)$, but mutant $\mathrm{CHO}$ cells that produce a dominant positive form of SREBP-2 have marked overexpression of endogenous HMG CoA reductase $(18,19)$. These findings suggest that the HMG CoA reductase gene is also activated by SREBPs.

In addition to genes involved in cholesterol metabolism, genes involved in fatty acid synthesis have also been reported to be activated by SREBPs. These include the genes for acetyl CoA carboxylase (24) and fatty acid synthase (25).

In cultured cells SREBP-1 and -2 are regulated coordinately. Each can act independently on the same genes, and there is no evidence that heterodimers are required $(12,13)$. Further heterogeneity is created by the production of alternative forms of the mRNA encoding SREBP-1 $(12,26)$. Two different promoters can be used, giving rise to two different first exons. The form designated SREBP-1a has a long acidic $\mathrm{NH}_{2}$-terminal transcription activating domain. The alternate form, designated SREBP-1c, has a shorter acidic domain. Both forms activate transcription when overexpressed in cultured cells, but their activities have not been compared quantitatively (12). SREBP-1 also has the potential to undergo alternative splicing at the $3^{\prime}$ end, generating two forms with different COOH-terminal sequences (12). In transfected cells, cleavage of the form with the shortest sequence is resistant to down-regulation by sterols (15).

The role of the SREBPs in regulating lipid synthesis in the liver has only begun to be explored. In the only published study, hamsters were fed a diet containing a bile acid binding resin (colestipol) and an HMG CoA reductase inhibitor (lovastatin) in order to deplete the liver of cholesterol (27). Livers from control hamsters on a chow diet contained the membranebound precursor and the mature nuclear form of SREBP-1. In contrast, SREBP-2 was found almost entirely in the membrane-bound precursor form. In livers of hamsters fed the cholesterol-depletion diet, the nuclear form of SREBP-1 declined, and this was balanced by an increase in the amount of SREBP-2 in the mature nuclear form. This was accompanied by an increase in the mRNA for HMG CoA synthase and the LDL receptor. It was concluded that the regulation of SREBPs is more complex in liver than in cultured fibroblasts and that the two SREBPs are not coordinately regulated in this organ (27).

In the current studies we have further explored the potential of SREBPs to regulate lipid metabolism in the liver by producing transgenic mice that overexpress a dominant-positive truncated form of SREBP-1a. These animals develop a massive fatty liver accompanied by marked increases in the mRNAs encoding enzymes of cholesterol and fatty acid synthesis and the LDL receptor. At the same time, the amount of white adi- pose tissue is markedly reduced. Remarkably, plasma lipid levels are not elevated in these animals. These results indicate that SREBP-1a can have a profound influence on expression of genes involved in lipid synthesis when overexpressed in mouse liver.

\section{Methods}

Materials and general methods. We obtained restriction and DNA modifying enzymes from New England Biolabs (Beverly, MA), Pfu DNA polymerase from Stratagene (Menasha, WI), Redivue [ $\alpha-$ $\left.{ }^{32} \mathrm{P}\right] \mathrm{dCTP}(3000 \mathrm{Ci} / \mathrm{mmol})$ and $\left[\alpha-{ }^{32} \mathrm{P}\right] \mathrm{UTP}(3000 \mathrm{Ci} / \mathrm{mmol})$ from Amersham (Arlington, IL), $\left[{ }^{3} \mathrm{H}\right]$ water from ICN, and goat anti-rabbit IgG from Organon Teknika Corp. (cat. No. 55641). DNA manipulations were performed using standard molecular techniques (28). Sequencing reactions were performed on an Applied Biosystem Model 373A DNA Sequencer by the dideoxy chain termination method (28). The content of cholesterol and triglycerides in plasma and liver was measured as described $(29,30)$.

Plasmid constructions. An expression plasmid encoding amino acids 1-460 of the human SREBP-1a cDNA under control of the rat PEPCK promoter was constructed in five steps, as follows. (a) A BglII fragment of the rat PEPCK promoter $(2.4 \mathrm{~kb})$, which contains sequence elements responsible for dietary regulation (31), was ligated into the BamHI site of the expression vector pCMV7 (12), which contains a $3^{\prime}$ polyadenylation signal from the human growth hormone cDNA. The resulting plasmid was designated pCMV-PEPCK promoter. (b) A cDNA fragment encoding amino acids 330-460 of human SREBP-1a followed by two consecutive terminator codons and a SalI site was generated by PCR using pSREBP-1a (12) as a template, Pfu polymerase, and the following primers: $5^{\prime}$ primer, $5^{\prime}$-GCCATTGAGAAGCGCTACCGCTCCTCCATCAATGAC-3'; and 3' primer, 5' -GTCGACCTACTAGTCAGGCTCCGAGTCACTGCCACTGCCACC-3'. The PCR product was subcloned into the SmaI site of pGEM3Zf $(+)$ (Promega, Madison, WI), and the resulting plasmid was designated pSREBP-1a(330-460). (c) A 1.1-kb EcoRI-Eco47III fragment of human SREBP-1a cDNA containing the 5' untranslated region and amino acids 1-333 was ligated into the EcoRI-Eco47III sites of pSREBP-1a(330-460). (d) A 4.0-kb EcoRI-SalI fragment of this plasmid was excised and ligated into the EcoRI-SalI site of the pCMV-PEPCK promoter plasmid. (e) A 1.7-kb SalI-SphI fragment containing the PEPCK promoter, SREBP-1a(1-460), and the $3^{\prime}$ polyadenylation signal was subcloned into $\operatorname{pGEM} 3 \mathrm{Zf}(+)$ to yield the final plasmid designated pPEPCK-SREBP-1a460. The integrity of the construct was confirmed by DNA sequencing.

Transgenic mice. Techniques used for generating transgenic mice were previously described (32). The SalI-SphI fragment of pPEPCKSREBP-1a460 was purified on a SeaKem GTG agarose gel (FMC Bioproducts, Rockland, ME) and isolated by perchlorate elution (33). A total of 326 fertilized eggs that were microinjected with the DNA fragment survived to the two-cell stage. Among the 38 offspring, $26 \%$ had integrated the transgene as determined by dot blot hybridization of DNA from tail homogenates (30). Of 10 founder mice subjected to partial hepatectomy, $50 \%$ produced truncated SREBP-1a as determined by immunoblot analysis (27). Mice with high levels of transgene expression in liver were bred to $\mathrm{C} 57 \mathrm{Bl} / 6 \mathrm{~J} \times$ SJL F1 mice, and seven lines of SREBP-1a460 transgenic mice were established. Two of the transgenic SREBP-1a460 founder mice contained copies of the transgene that were integrated at two sites. These were segregated by breeding.

Mice were housed in colony cages and maintained on a 14-h light/ 10-h dark cycle. The mice were fed Teklad 4\% (wt/wt) Mouse/Rat Diet 7001 from Harlan Teklad Premier Laboratory Diets (Madison, WI) or a synthetic low carbohydrate/high protein diet (No. 5789C-3) from Purina Mills Inc. (St. Louis, MO) containing $71 \%$ (wt/wt) casein and $4.25 \%$ (wt/wt) sucrose. Before being killed, transgenic animals and littermate controls were placed on the low carbohydrate/high protein 
Table I. Sequences of PCR Primers for Cloning Mouse cDNA Probes

\begin{tabular}{|c|c|c|c|c|}
\hline cDNA Probe & $\begin{array}{l}\text { Primer } \\
\text { pair }\end{array}$ & Primer sequences & $\begin{array}{c}\text { PCR } \\
\text { product }\end{array}$ & References \\
\hline & & & $b p$ & \\
\hline \multirow[t]{2}{*}{ SREBP-1 } & $5^{\prime}$ & 5'-TCAACAACCAAGACAGTGACTTCCCTGGCC-3' & 1028 & 12,17 \\
\hline & $3^{\prime}$ & 5'-GTTCTCCTGCTTGAGCTTCTGGTTGCTGTG-3' & & \\
\hline \multirow[t]{2}{*}{ SREBP-2 } & $5^{\prime}$ & 5'-CATGGA(C/G)ACCCTCACGGAGCTGGGCGACGA-3' & 1334 & 13,19 \\
\hline & $3^{\prime}$ & 5'-TGCATCATCCA(G/A)(C/T)AGAGG(A/G)CTTCCTGGCTC-3' & & \\
\hline \multirow[t]{2}{*}{ HMG CoA Synthase } & $5^{\prime}$ & 5'-TATGATGGTGTAGATGCTGGGAAGTATACC-3' & 1283 & 44,45 \\
\hline & $3^{\prime}$ & 5'-TAAGTTCTTCTGTGCTTTTCATCCAC-3' & & \\
\hline \multirow[t]{2}{*}{ HMG CoA Reductase } & $5^{\prime}$ & 5'-GGGACGGTGACACTTACCATCTGTATGATG-3' & 882 & 46 \\
\hline & $3^{\prime}$ & 5'-ATCATCTTGGAGAGATAAAACTGCCA-3' & & \\
\hline \multirow[t]{2}{*}{ Fatty Acid Synthase } & $5^{\prime}$ & 5'-GGCTTTGGCCTGGAACTGGCCCGGTGGCT-3' & 1286 & 47,48 \\
\hline & $3^{\prime}$ & 5'-TCGAAGGCTACACAAGCTCCAAAAGAATA3' & & \\
\hline \multirow[t]{2}{*}{ Acetyl-CoA Carboxylase } & $5^{\prime}$ & 5'-GGGACTTCATGAATTTGCTGATTCTCAGTT-3' & 729 & 49,50 \\
\hline & $3^{\prime}$ & 5'-GTCATTACCATCTTCATTACCTCAАTCTC-3' & & \\
\hline \multirow[t]{2}{*}{ Squalene Synthase } & $5^{\prime}$ & 5'-ATGGAGTTCGTCAAGTGTCTAGGCCACCCG-3' & 672 & 51 \\
\hline & $3^{\prime}$ & 5'-TTGGTCTTCCAGATAATCACGAATGATATT-3' & & \\
\hline \multirow[t]{2}{*}{ Stearoyl-CoA Desaturase-1 } & $5^{\prime}$ & 5'-GGAAAGTGAGGCGAGCAACTGACTATCATC-3' & 348 & 52 \\
\hline & $3^{\prime}$ & 5'-GGTCATGTAGTAGAAAATCCCGAAGAGGGC-3' & & \\
\hline \multirow[t]{2}{*}{ ApoAI } & $5^{\prime}$ & 5'-GGCAGAGACTATGTGTCCCAGTTTGA-3' & 564 & 53,54 \\
\hline & $3^{\prime}$ & 5'-GTCATCCAGCGCGGGTTTGGCCTTCTC-3' & & \\
\hline \multirow{2}{*}{ ApoB } & $5^{\prime}$ & 5'-GACAGTGTCAACAAGGCTTTGTA(T/C)TGGGT-3' & 593 & 55,56 \\
\hline & $3^{\prime}$ & 5'-GGCAGAGACTATGTGTCCCAGTTTGA-3' & & \\
\hline \multirow[t]{2}{*}{ ApoE } & $5^{\prime}$ & 5'-TGGGAGCAGGCCCTGAACCGCTTC-3' & 237 & 57 \\
\hline & $3^{\prime}$ & 5'-GAGTCGGGCCTGTGCCGCCTGCAC-3' & & \\
\hline
\end{tabular}

diet for two weeks to induce maximal expression of the transgene. Mice used in exp. A of Table II were killed in the nonfasting state during the early phase of the light cycle. Mice used in exp. B of Table II were killed after a 4-h fast during the early phase of the light cycle.

cDNA probes. cDNA probes for the mouse LDL receptor (34), mouse cholesterol $7 \alpha$ - hydroxylase (35), and rat glyceraldehyde-3-phosphate dehydrogenase (GAPDH) (36) were prepared as described in the indicated references. Probes for 11 other mouse cDNAs were synthesized as follows. First-strand cDNA was prepared from mouse liver poly $(\mathrm{A})^{+}$RNA using SuperscriptII (GIBCO-BRL) primed with
oligo-dT. The cDNA was used as a template in PCR reactions with the primer pairs listed in Table I. The resulting PCR products were subcloned into pPCRII (Invitrogen, San Diego, CA) and purified on agarose gels. All cDNA probes were radiolabeled with $\left[\alpha-{ }^{32} \mathrm{P}\right] \mathrm{CTP}$ using the Megaprime DNA Labeling System (Amersham).

Blot hybridization of RNA. Total RNA was prepared from mouse liver using an RNeasy ${ }^{\mathrm{TM}}$ Total RNA Kit (Qiagen, Chatsworth, CA). For Northern gel analysis, equal aliquots of total RNA $(2.5 \mu \mathrm{g})$ from six mice were pooled (total, $15 \mu \mathrm{g}$ ), denatured with formaldehyde and formamide, subjected to electrophoresis in a $1 \%$ agarose gel, and

Table II. Phenotypic Differences between Wild-type and TgSREBP-1a460 Transgenic Mice

\begin{tabular}{|c|c|c|c|c|}
\hline \multirow[b]{2}{*}{ Parameter } & \multicolumn{2}{|c|}{ Exp. A } & \multicolumn{2}{|c|}{ Exp. B } \\
\hline & Wild-type & TgSREBP-1a460 & Wild-type & TgSREBP-1a460 \\
\hline Sex & 4 males, 2 females & 5 males, 1 female & 6 females & 6 females \\
\hline Body weight $(\mathrm{g})$ & $25.6 \pm 1.9$ & $25.3 \pm 1.8$ & $21.3 \pm 1.3$ & $23.9 \pm 1.1$ \\
\hline Liver weight $(\mathrm{g})$ & $1.5 \pm 0.1$ & $3.6 \pm 0.8$ & $1.2 \pm 0.1$ & $5.1 \pm 0.3$ \\
\hline Epididymal fat pad weight (g) & $0.31 \pm 0.07$ & $0.012 \pm 0.006$ & --- & --- \\
\hline Liver cholesterol content $(\mathrm{mg} / \mathrm{g})$ & $2.1 \pm 0.1$ & $8.0 \pm 1.7$ & $2.0 \pm 0.1$ & $9.4 \pm 0.7$ \\
\hline Liver triglyceride content $(\mathrm{mg} / \mathrm{g})$ & $12.8 \pm 3.1$ & $150 \pm 38$ & $11 \pm 1.7$ & $232 \pm 14$ \\
\hline Total plasma cholesterol $(\mathrm{mg} / \mathrm{dl})$ & $84 \pm 5.2 *$ & $86 \pm 11 *$ & $42 \pm 2.6^{\ddagger}$ & $46 \pm 10^{\ddagger}$ \\
\hline Total plasma triglycerides $(\mathrm{mg} / \mathrm{dl})$ & $169 \pm 11 *$ & $159 \pm 34 *$ & $137 \pm 23^{\ddagger}$ & $78 \pm 4.2^{\ddagger}$ \\
\hline
\end{tabular}

Each value represents the mean \pm SEM of the indicated number of 16 -wk-old mice of the indicated sex except for the values for epididymal fat pad weight, which were obtained on male mice only. In each experiment, the wild-type mice consisted of nontransgenic littermates of the transgenic mice. The TgSREBP-1a460 mice were obtained from two lines that were segregated from a double integrant founder. In exp. A, 2 of the transgenic mice were high expressors of the transgene and 4 were low expressors (lines B and E, respectively; see Figure 4). In exp. B, all 6 transgenic mice were high expressors (line B; see Fig. 4). All mice were fed the low carbohydrate/high protein diet for 2 wk before death. *Nonfasted plasma samples. ${ }^{\ddagger}$ Plasma obtained after a 4-h fast. 
transferred to Hybond $\mathrm{N}+$ membranes (Amersham) for hybridization. The filters were hybridized with the indicated ${ }^{32} \mathrm{P}$-labeled probes $\left(\sim 1 \times 10^{6} \mathrm{cpm} / \mathrm{ml}\right)$ for $2 \mathrm{~h}$ at $65^{\circ} \mathrm{C}$ using Rapid-hyb buffer (Amersham), washed with $0.1 \%$ (wt $/ \mathrm{vol}$ ) SDS $/ 0.1 \times \mathrm{SSC}$ at $70^{\circ} \mathrm{C}$ for $60 \mathrm{~min}$, and exposed at $-80^{\circ} \mathrm{C}$ to Reflection ${ }^{\mathrm{TM}} \mathrm{NEF} 496$ film (NEN-DuPont) with intensifying screens for $3-36 \mathrm{~h}$ at $-80^{\circ} \mathrm{C}$ or for $0.15-3 \mathrm{~h}$ at room temperature. The resulting bands were quantified by exposure of the dried filter to a BAS1000 Fuji Photoimager, and the results were normalized with regard to the signal generated from GAPDH mRNA (obtained from the same filter). All film exposures for GAPDH were done for $3 \mathrm{~h}$ at $-80^{\circ} \mathrm{C}$ with intensifying screens.

RNase protection assay. A cDNA for mouse lipoprotein lipase was cloned from first strand cDNA prepared from mouse epididymal fat total RNA. The cDNA was used as a template in a PCR reaction with the following primers based on the published mouse sequence (37). A BamHI site was added to the $5^{\prime}$ primer and an EcoRI site to the $3^{\prime}$ primer: 5' primer, 5'-GGATCCGTGGCCGCAGCAGACGCAGGAAGA-3'; and $3^{\prime}$ primer, 5'-GAATTCCATCCAGTTGATGAATCTGGCCAC-3'. The resulting 366-bp PCR product was subcloned into pGEM-T vector (Promega). After linearization with BamHI, antisense RNA was transcribed using SP6 RNA polymerase with $\left[\alpha-{ }^{32} \mathrm{P}\right] \mathrm{UTP}(3,000 \mathrm{Ci} / \mathrm{mmole})$. Specific activities were obtained in the range of $1.7-2.6 \times 10^{9} \mathrm{cpm} / \mu \mathrm{g}$.

As an internal control, a cDNA for mouse $\beta$-actin was prepared as described above except that mouse liver poly $(\mathrm{A})^{+}$RNA and the following primers based on the mouse $\beta$-actin sequence (38) were used: 5' primer, 5'-GGATCCCAGATCATGTTTGAGACCTTCAAC-3'; and 3' primer, 5'-GAATTCGGAGAGCATAGCCCTCGTAGATGG-3'. The resulting 167-bp PCR product was subcloned into pGEM-T (Promega), and T7 RNA polymerase was used to make the antisense RNA after linearization with BamHI as described above.

Aliquots of total RNA $(10 \mu \mathrm{g})$ from liver (described above) and from epididymal fat pads of four $\mathrm{C} 57 \mathrm{Bl} / 6 \mathrm{~J}$ mice were subjected to an RNase protection assay using the HybSpeed ${ }^{\mathrm{TM}}$ RPA kit (Ambion, cat. No. 1412). The mRNA-protected, ${ }^{32} \mathrm{P}$-labeled probes were separated on $8 \mathrm{M}$ urea $/ 4.8 \%$ polyacrylamide gels, and the radioactivity in each band was quantified using the Fuji Photoimager. The film was exposed for $8 \mathrm{~h}$ at room temperature.

Antibodies and immunoblot analysis. A rabbit polyclonal antibody against human SREBP- 1 (amino acids 31-175) was prepared as previously described (11). A polyclonal antibody against mouse SREBP-1
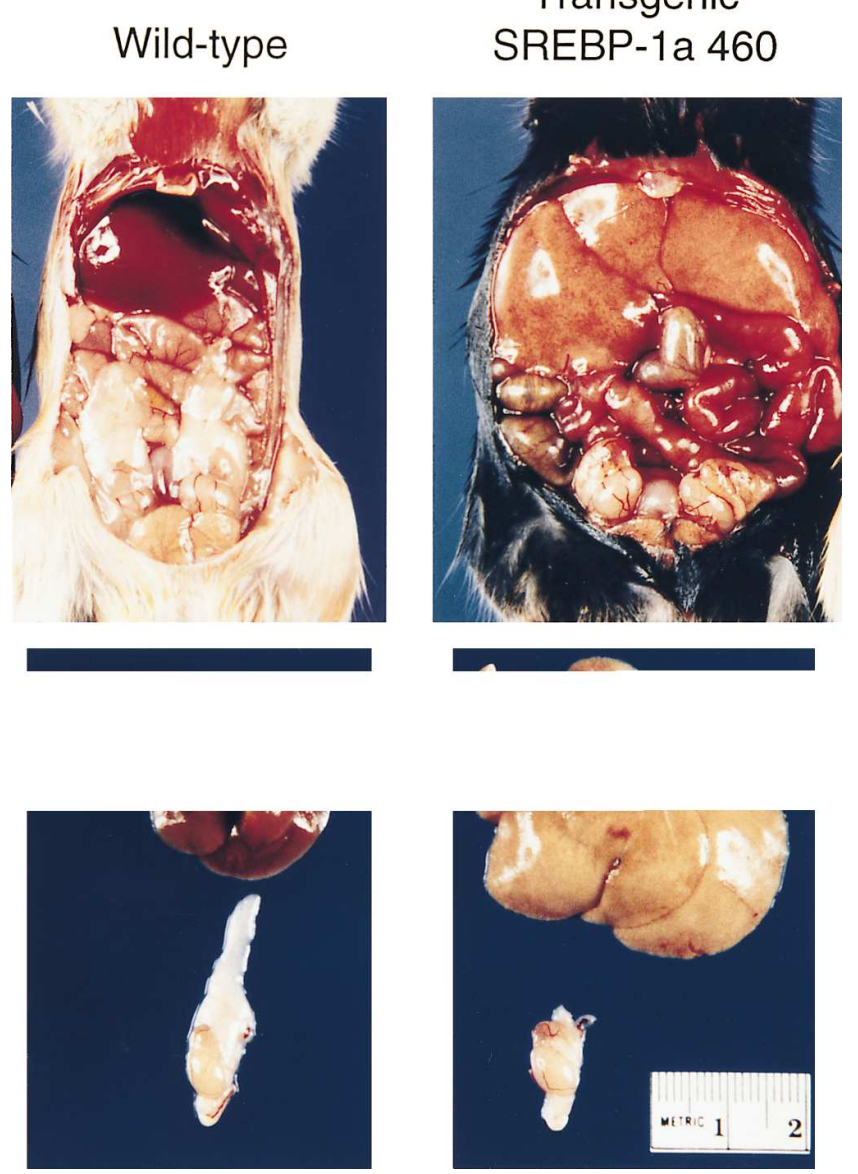

Figure 1. Photographs of 18-wk-old wild-type (left) and transgenic SREBP-1a460 (right) littermate male mice. Both animals were fed the low carbohydrate/high protein diet for $2 \mathrm{wk}$ before the time of the photograph. The upper panels show a ventral view, illustrating the enlarged fatty liver and marked reduction of epididymal fat in the transgenic mouse (right) as compared with the wild-type mouse (left). The lower panels show the gross morphology of the liver, the epididymal fat, and the testis from a wild-type (left) and transgenic (right) mouse.
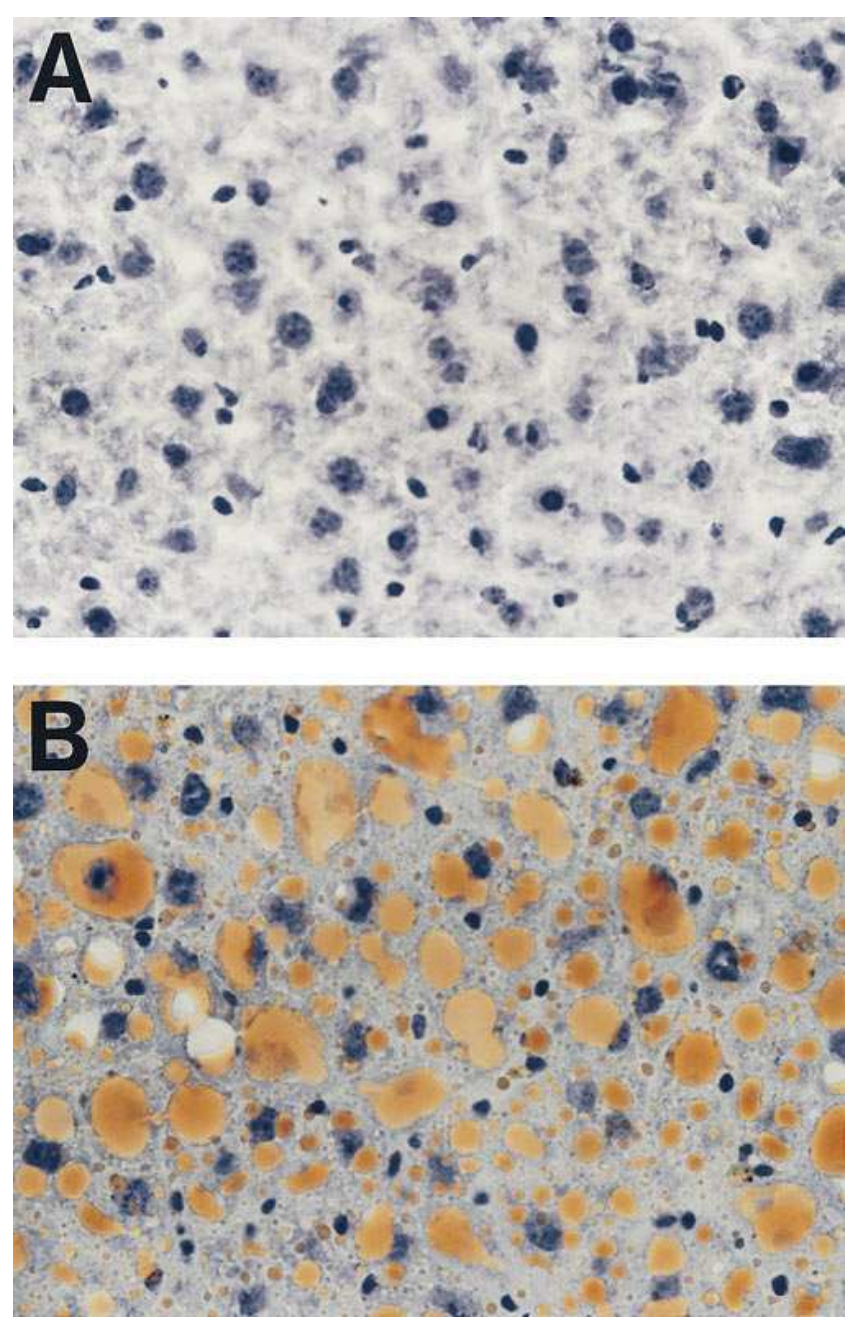

Figure 2. Representative photomicrographs of liver from 16-wk-old wild-type $(A)$ and SREBP-1a460 $(B)$ mice. All animals were fed the low carbohydrate/high protein diet for $2 \mathrm{wk}$ before the time of death. Liver samples were frozen in O.C.T. (Miles, Inc.) with liquid nitrogen, and $8-\mu \mathrm{m}$ sections were cut and stained with Sudan IV. Note the marked lipid accumulation in the liver from the SREBP-1a460 mouse. $\times 378$. 
was prepared by immunizing rabbits with a bacterially produced His(6)-tagged protein containing amino acids 32-250. A plasmid encoding the His-tagged fusion protein was produced by PCR using first strand cDNA from mouse liver as a template. The PCR product was subcloned in the pQE30 vector (Qiagen) and used to transform $E$. coli strain M15[pREP4] (Qiagen). The resultant protein was purified by $\mathrm{Ni}^{2+}$ affinity chromatography (Qiagen) and injected into rabbits (12). IgG fractions of all antibodies were prepared by Protein A/G affinity chromatography (Pierce, Rockford, IL).

For immunoblot analysis, membranes $\left(10^{5} \mathrm{~g}\right.$ pellet) and nuclear extracts from mouse liver samples were prepared immediately after exsanguination as previously described for hamster liver (27). Aliquots of the membranes and nuclear extracts were subjected to $8 \%$ SDS-PAGE, transferred to Hybond $\mathrm{C}$ extra membranes (Amersham), and incubated with either $5 \mu \mathrm{g} / \mathrm{ml}$ of rabbit anti-human SREBP-1 IgG (11), $5 \mu \mathrm{g} / \mathrm{ml}$ rabbit anti-mouse SREBP-1 IgG (described above), or $5 \mu \mathrm{g} / \mathrm{ml}$ of rabbit anti-mouse SREBP-1 IgG conju-

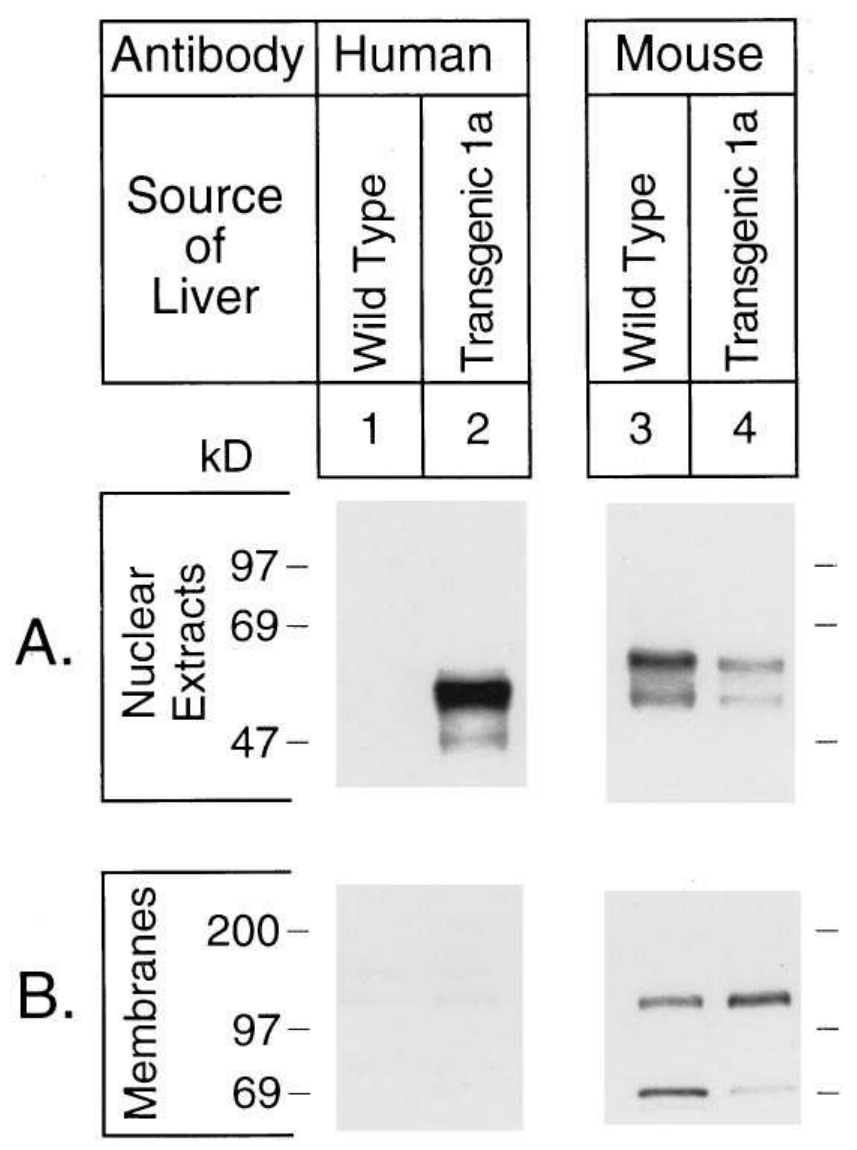

Figure 3. Immunoblot analysis of human SREBP-1a460 (lanes 1 and 2 ) and endogenous mouse SREBP-1 (lanes 3 and 4 ) in nuclear extracts $(A)$ and membranes $(B)$ from livers of wild-type mice (lanes 1 and 3 ) and TgSREBP-1a460 mice (lanes 2 and 4 ). For each group, livers from the six mice shown in exp. B of Table II were pooled, and aliquots (30 $\mu \mathrm{g}$ protein) of nuclear extracts $(A)$ and membranes $(B)$ were subjected to SDS-PAGE. (Lanes 1 and 2) Immunoblot analysis was performed with the ECL system using $5 \mu \mathrm{g} / \mathrm{ml}$ of rabbit anti-human SREBP-1 $\mathrm{IgG}$ as the primary antibody and $0.25 \mu \mathrm{g} / \mathrm{ml}$ horseradish peroxidase-labeled donkey anti-rabbit IgG (Amersham) as the secondary antibody. (Lanes 3 and 4) Immunoblot analysis was carried out with $5 \mu \mathrm{g} / \mathrm{ml}$ of horseradish peroxidase-labeled polyclonal antimouse SREBP-1 IgG as the primary antibody. Bound antibodies were visualized with the ECL system. Filters were exposed to film for $10 \mathrm{~s}$ (lanes 1 and 2) or $20 \mathrm{~s}$ (lanes 3 and 4 ) at room temperature. gated to horseradish peroxidase (Pierce). Immunoblot analysis was carried out by either of two methods. Method 1 used the Enhanced Chemiluminescence (ECL) Western Blotting Detection System Kit ${ }^{\mathrm{TM}}$ (Amersham) with a horseradish-peroxidase coupled first or second antibody and wash conditions as previously described (27). Method 2 used autoradiography with $2 \mu \mathrm{g} / \mathrm{ml}{ }^{125}$ I-labeled goat anti-rabbit IgG $\left(4 \times 10^{6} \mathrm{cpm} / \mathrm{ml}\right)$ as the secondary antibody as previously described (39). The wash conditions in Method 2 were as follows: two washes at room temperature with phosphate buffered saline (Sigma, Cat. No. P3563) supplemented with $0.1 \%$ (wt/vol) SDS, $1 \%$ (vol/vol) Nonidet $\mathrm{P}-40$, and $0.5 \%(\mathrm{wt} / \mathrm{vol})$ sodium deoxycholic acid. Protein gels were calibrated with prestained Rainbow markers (Amersham). Protein content of samples was determined with the BCA Kit (Pierce).

Hepatic cholesterol and fatty acid synthesis in vivo. Rates of cholesterol and fatty acid synthesis were measured in littermate 8-wk-old mice (four wild-type and six transgenic mice) during the early light cycle after a 2-h fast. Before the fast, the mice had been fed a low carbohydrate/high protein diet for $2 \mathrm{wk}$. Each animal was injected intraperitoneally with $50 \mathrm{mCi}$ of $\left[{ }^{3} \mathrm{H}\right]$ water in $0.1 \mathrm{ml}$ of isotonic saline (40). $1 \mathrm{~h}$ after injection, each animal was anesthetized, and 300-500 $\mu \mathrm{l}$ of blood was removed from the inferior vena cava and used to measure the plasma $\left[{ }^{3} \mathrm{H}\right]$ water specific activity in duplicate. The liver was removed, and 200-300 mg portions were saponified, and the digitoninprecipitable sterols were isolated as previously described (41). Fatty

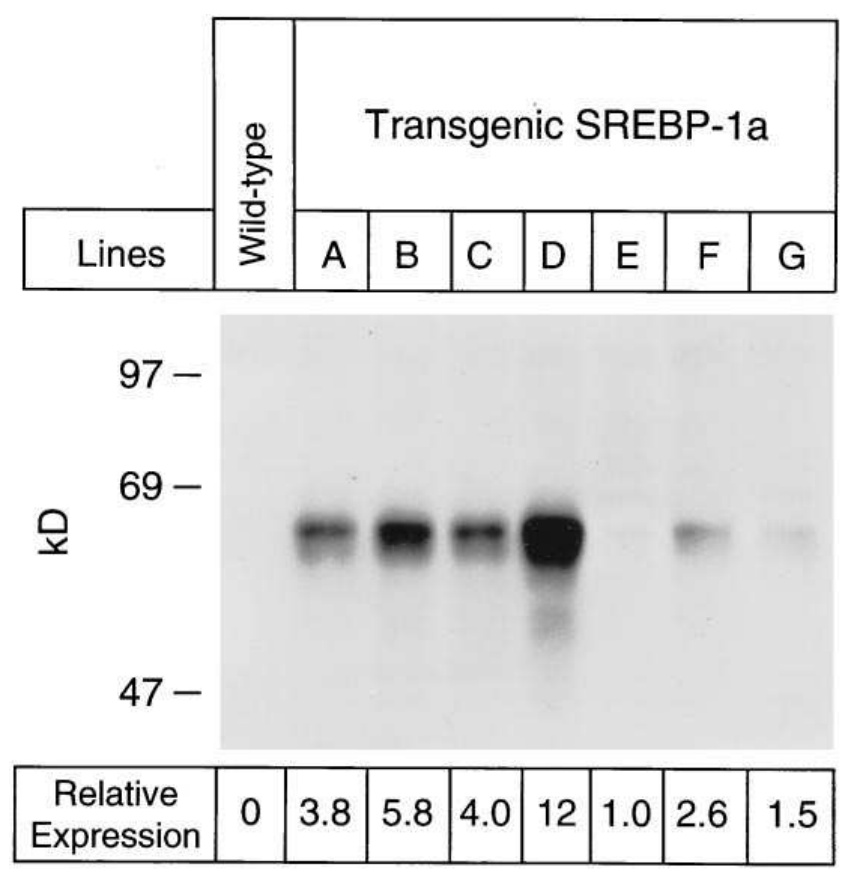

Figure 4. Expression of SREBP-1a460 in livers from seven different lines of transgenic SREBP-1a460 mice. Nuclear extracts were prepared from pooled or individual liver samples as indicated below. Aliquots of the hepatic nuclear extracts ( $60 \mu \mathrm{g}$ protein) from wild-type mice or transgenic SREBP-1a460 mice (lanes $A-G$ ) were subjected to SDS-PAGE and immunoblot analysis using $5 \mu \mathrm{g} / \mathrm{ml}$ of polyclonal anti-human SREBP-1 IgG as the primary antibody and $2 \mu \mathrm{g} / \mathrm{ml}$ of ${ }^{125}$ I-labeled goat anti-rabbit IgG as the secondary antibody as described in Methods. Membranes were exposed to film for $6 \mathrm{~h}$ at $-80^{\circ} \mathrm{C}$. The amount of radioactivity in each band was quantified using a Bio-Imaging Analyzer with BAS 1000 MacBAS software (Fuji Medical Systems). The relative levels of transgenic SREBP-1a460 protein are plotted at the bottom of the figure and normalized to the liver sample showing the lowest expression (E). The number of mice in each pool were as follows: wild-type, 4; A, 4; B, 3; C, 2; D, 3; E, 4; F, $1 ; \mathrm{G}, 1$. 
acids were extracted from the same samples with $10 \mathrm{ml}$ of petroleum ether after acidification with $1 \mathrm{ml}$ of concentrated $\mathrm{HCl}$ (42), followed by a second extraction and evaporation of the petroleum ether. The rates of hepatic cholesterol and fatty acid synthesis were calculated as the $\mu \mathrm{mol}$ of $\left[{ }^{3} \mathrm{H}\right]$ water incorporated into digitonin-precipitable sterols or fatty acids per hour per gram of tissue (43).

\section{Results}

In designing the current studies, we chose to use the 2.4-kb BglII fragment of the PEPCK promoter (31) to drive expression of SREBP-1a460 for three reasons: $(a)$ it is not expressed in fetal life but becomes active only after birth; $(b)$ although it is expressed in many organs, it is expressed highly in the liver relative to other organs; and (c) its expression can be induced by placing the animals on a low carbohydrate/high protein diet, and repressed by a high carbohydrate diet (31).

Transgenic mice expressing SREBP-1a460 appeared normal at birth. One day after birth, the abdomen began to swell, owing to liver enlargement. The liver enlarged further after weaning when animals were placed on a synthetic low carbohydrate/high protein diet, which further induces expression of the PEPCK promoter in liver. Aside from the abdominal enlargement, the animals appeared grossly normal. Their body weights were similar to those of nontransgenic littermates (Table II).

The upper panels of Fig. 1 show photographs of the opened abdominal cavities of 18-wk-old wild-type and TgSREBP1a460 mice after consumption of the low carbohydrate/high protein diet for two weeks. The liver of the transgenic animal is grossly enlarged and pale in color, owing to the massive accumulation of lipid. In contrast, there is a marked decrease in the amount of subcutaneous, omental, perirenal, and epididymal fat. The bottom panels of Fig. 1 show the excised livers and epididymal fat pads, illustrating the marked enlargement of the former and the diminution in the latter in the transgenic mouse.

Fig. 2 compares the histologic appearance of a liver from a 16-wk-old wild-type mouse and a transgenic mouse fed the low carbohydrate/high protein diet for $2 \mathrm{wk}$ before death. Most of the hepatocytes are distended by fat droplets. There is no generalized inflammation, and no sign of necrosis.

Table II shows a comparison of quantitative parameters as measured in two experiments with 16-wk-old TgSREBP-1a460 mice and their nontransgenic littermates. All mice were fed the low carbohydrate/high protein diet for $2 \mathrm{wk}$. In exp. A, two of the mice expressed high levels of the transgene, and four expressed relatively low levels. In exp. B all of the mice were high expressors. Liver weights were increased by up to fourfold, and the weight of the epididymal fat pads was reduced by more than $90 \%$ in the transgenic mice. The liver's content of cholesterol was elevated 4.7-fold, and the triglyceride content was elevated by up to 21 -fold when calculated on a $\mathrm{mg} / \mathrm{g}$ liver weight basis. Considering the increase in liver weight, the total amounts of cholesterol and triglyceride in the organ were increased by 20 -fold and 90 -fold, respectively. Plasma cholesterol was normal, and there was a modest decrease in plasma triglycerides in the transgenic mice.

As expected, nuclear extracts from livers of transgenic mice contained the truncated SREBP-1a, as visualized with an antibodyspecific for the human protein (Fig. $3 A$, lane 2). An antibody specific for endogenous mouse SREBP-1 was used to visualize the mature nuclear form as well as the $120-\mathrm{kD}$ membrane-bound precursor form (Figs. 3, $A$ and $B$, lanes 3 and 4 ).
Inasmuch as we do not know whether the endogenous protein is SREBP-1a or -1c, we use the generic term SREBP-1. The amount of the nuclear form was reduced in the transgenic mice (Fig. $3 A$, lane 4). The nuclear form of SREBP-1 runs as a doublet, possibly attributable to proteolysis and/or phosphorylation. In addition to the $125-\mathrm{kD}$ precursor form of endogenous SREBP-1, the membrane fractions from the wild-type and transgenic mouse livers contained a band at about 69-kD (Fig. $3 \mathrm{~B}$, lanes 3 and 4 ) that may represent the membrane-bound intermediate that is generated after the first proteolytic cleavage in the lumenal loop (16). The amount of this intermediate form was reduced in the transgenic mice, as was the mature nuclear form.

We established seven lines of transgenic mice, designated A-G, that were derived from five different founders. These mice produced varying amounts of truncated SREBP-1a as determined by immunoblot analysis of nuclear extracts (Fig. 4). Fig. 5 shows that the amount of triglyceride in the livers of the transgenic mice was generally proportional to the level of expression of the truncated SREBP-1a. Mice from line B were used for most of the experiments in this paper.

Fig. 6 shows the amounts of 14 mRNAs in wild-type and transgenic mouse livers as determined by Northern blot analysis. As a control for loading of mRNA, we hybridized the same filters with a probe against GAPDH. Radioactivity was quantified with a phosphoimager, and the fold-increase in each mRNA, corrected for loading with GAPDH, was calculated. The mRNAs for endogenous SREBP-1 and SREBP-2 were elevated 3.6- and 1.6-fold, respectively. Among the cholesterol biosynthetic enzymes, the greatest fold increase was observed for $\mathrm{HMG}$ CoA reductase (37-fold). The mRNAs for $\mathrm{HMG}$ CoA synthase and squalene synthase were elevated to a somewhat lesser degree. The mRNA for the LDL receptor was ele-

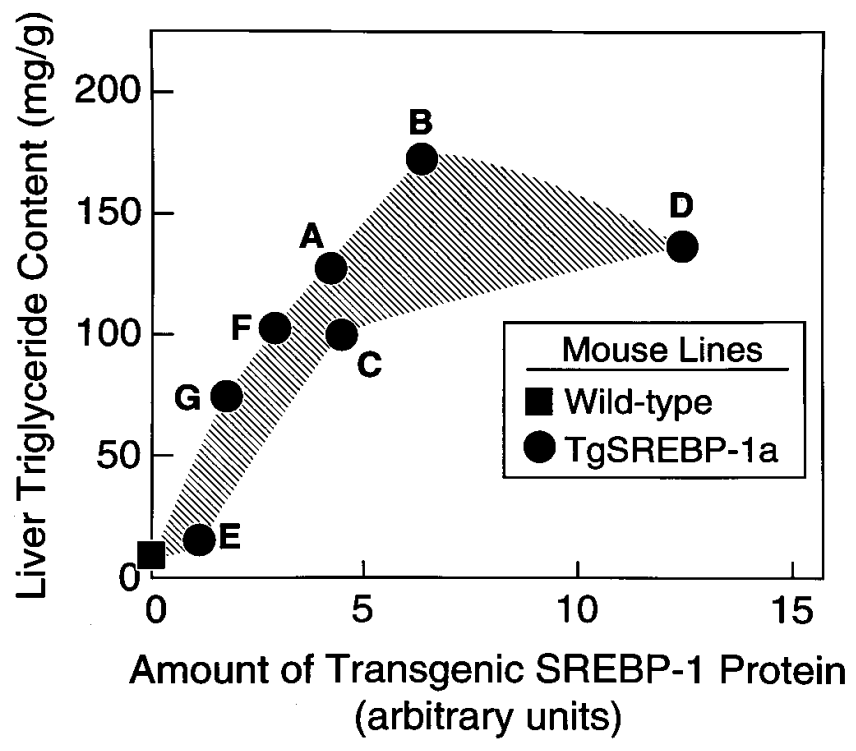

Figure 5. Relation between amounts of transgenic SREBP-1a460 protein and triglycerides in livers of transgenic SREBP-1a460 mice from seven different transgenic lines. The amounts of SREBP-1a460 are taken from the data of Fig. 4. The content of triglycerides was measured in the liver of each mouse as described in Methods. The data are plotted as the mean values for all groups except $F$ and $G$, which are individual values. 
vated 6.6-fold. The mRNAs encoding two enzymes of fatty acid synthesis, acetyl-CoA carboxylase and fatty acid synthetase, were markedly elevated (17- and 20-fold, respectively). There was also a pronounced 3.9-fold increase in the mRNA encoding stearoyl CoA desaturase-1, which introduces the first double bond into saturated fatty acids. The mRNAs encoding three apoproteins (A, B, and E) were unchanged in livers of the transgenic mice, and there was a minor decrease in the mRNA for cholesterol $7 \alpha$-hydroxylase.

The liver of the normal mouse expresses only a trace amount of mRNA for lipoprotein lipase (37). To determine whether this mRNA is increased in the transgenic mouse livers, we established a sensitive nuclease protection assay using radiolabeled RNA probes. Fig. 7 shows that the livers of the transgenic mice contained $\sim 25$-fold more lipoprotein lipase mRNA than did wild-type livers. The level in transgenic liver was about one-sixth of the level seen in wild-type adipose tissue, the richest source of lipoprotein lipase.

To confirm that the elevated mRNAs for the lipogenic enzymes were leading to enhanced lipid synthesis in the transgenic mouse livers, we performed an in vivo biosynthetic ex- periment with $\left[{ }^{3} \mathrm{H}\right]$ water as a tracer (41-43). Wild-type and transgenic mice were given a dose of $\left[{ }^{3} \mathrm{H}\right]$ water intraperitoneally. After $60 \mathrm{~min}$, the livers were excised, and the content of ${ }^{3} \mathrm{H}$-labeled digitonin-precipitable sterols and total fatty acids were measured (Table III). The transgenic mice exhibited a 5- and 25-fold increase in these two parameters, respectively, when expressed per gram of liver. The fold-increase was even greater when the difference in the size of the livers are taken into account. It should be noted that the mice used in this experiment were 8 wk old, as compared with the 16-wk-old animals used in the experiment of Table II, and this accounts for the difference in liver weights between the two experiments.

Despite the gross engorgement of the liver with lipids, routine blood chemistries in the transgenic mice were nearly normal. Blood was obtained from three nonfasting transgenic mice from line B and three wild-type mice at 9 wk of age after consumption of the low carbohydrate/high protein diet for 2 wk. The levels of glucose, creatinine, and blood urea nitrogen were virtually the same in the two groups. Importantly, the serum albumin in the transgenic mice was, if anything, higher than that in the wild-type mice ( $2.63 \mathrm{vs.} 2.07 \mathrm{~g} / \mathrm{dl}$, respectively)
A

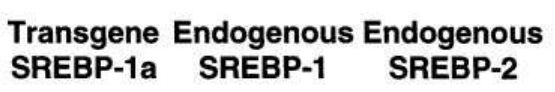


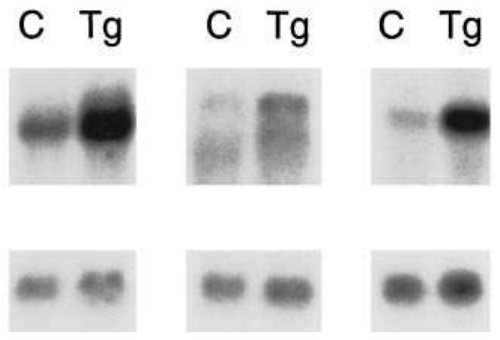

3.6

1.6

K

L

ApoAl

Acetyl CoA

J

Stearoyl CoA

Carboxylase

Fatty Acid Stearoyi CoA
Synthase Desaturase-1

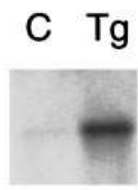

C $\mathrm{Tg}$


C $\mathrm{Tg}$
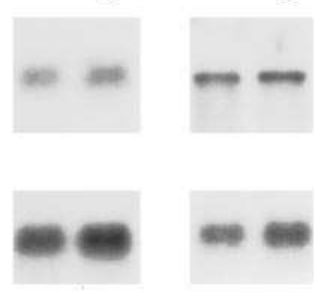

3.9
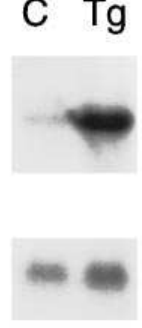

6.1

E

HMG CoA Synthase

C

Reductase
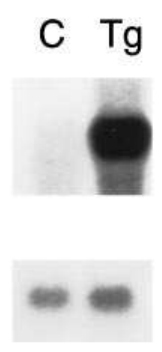

37
5.4

H

Squalene Cholesterol Synthase $7 \alpha$-hydroxylase
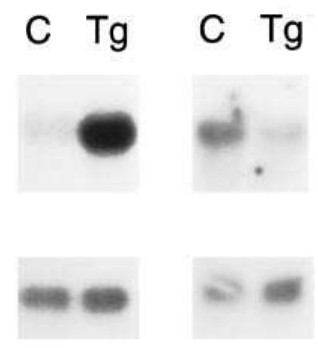

0.5

Fold Increase

1.0

N

ApoE
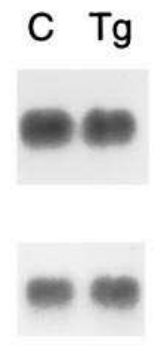

0.9

Figure 6. Amounts of various mRNAs in livers of wild-type and TgSREBP-1a460 mice as measured by blot hybridization. The animals used in this experiment are described in exp. B of Table II. Total RNA isolated from six mice was pooled and subjected to electrophoresis and blot hybridization with the indicated ${ }^{32} \mathrm{P}$-labeled probe and with a control ${ }^{32} \mathrm{P}$-labeled probe directed against GAPDH. The amount of radioactivity in each band was quantified with a Bio-Imaging Analyzer as described in the legend to Fig. 4. The fold-increase in mRNA, relative to that of wild-type control mice, was calculated after correction for loading differences with GAPDH. These values are shown below each blot. 


\begin{tabular}{|c|c|c|c|}
\hline Tissue & \multicolumn{2}{|c|}{ Liver } & Fat \\
\hline Genotype & WT & Tg & WT \\
\hline Relative Level & 1 & 25 & 165 \\
\hline
\end{tabular}

Figure 7. Amounts of lipoprotein lipase mRNA in liver tissue from wild-type (lane $A$ ) and TgSREBP-1a460 (lane $B$ ) mice as measured by RNase protection. The animals used for liver RNA are described in Fig. 6. Lane $C$ contains RNA from the epididymal fat of C57Bl/6J mice. Aliquots of total RNA $(10 \mu \mathrm{g})$ from the indicated source were hybridized with ${ }^{32} \mathrm{P}$-labeled riboprobes, and protected bands were separated by polyacrylamide gel electrophoresis, exposed to film, and quantified as described in Methods. The relative levels of lipoprotein lipase mRNA are normalized to the level in liver from wild-type mice. WT, wild-type; Tg, transgenic; LPL, lipoprotein lipase.

as was the total protein level $(6.8 \mathrm{~g} / \mathrm{dl}$ vs. $5.87 \mathrm{~g} / \mathrm{dl})$. The aspartate aminotransferase value was slightly elevated in the transgenic mice $(640 \mathrm{U} / \mathrm{ml}$ vs. $400 \mathrm{U} / \mathrm{ml})$, but the alkaline phosphatase and bilirubin levels were normal.

\section{Discussion}

The current data demonstrate that overexpression of a truncated nuclear form of SREBP-1a profoundly alters lipid synthesis in the liver of mice. The amounts of mRNA encoding at least three cholesterogenic enzymes (HMG CoA reductase, HMG CoA synthase, and squalene synthase) and two enzymes of fatty acid biosynthesis (acetyl CoA carboxylase and fatty acid synthase) were markedly elevated, as was the mRNA encoding the LDL receptor. As a result, the rates of synthesis of cholesterol and fatty acids were markedly increased, and the liver's content of cholesterol and triglyceride increased dramatically and progressively. Hepatocytes were engorged with lipid droplets, but there was no sign of inflammation or necrosis. Remarkably, blood lipid levels were essentially unaffected.

These results are generally consistent with the known properties of SREBP-1a as deduced from studies in transfected fibroblasts (11-25). These studies indentified the genes encoding cholesterogenic and fatty acid biosynthetic enzymes as direct targets of SREBP-1a action. The current data indicate that SREBP-1a can function in liver as well as in fibroblasts and that the amounts of nuclear SREBPs can be rate-limiting for the synthesis of cholesterol and fatty acids.

The marked increase in the mRNAs encoding the fatty acid biosynthetic enzymes and the accumulation of lipid droplets suggest that truncated SREBP-1a can induce some aspects of the adipose tissue metabolic program in hepatocytes. Consistent with this finding is the increase in the mRNA encoding lipoprotein lipase. These effects do not represent a complete change in differentiated phenotype, however, because the normal hepatic functions continue to be performed. Thus, the amount of mRNA for apoB, an mRNA specific for liver and intestine, did not change (Fig. 6). Moreover, the level of serum albumin, an indicator of hepatic function, did not fall in the transgenic mice.

The increase in the mRNAs for the cholesterogenic enzymes is most impressive when considered in relation to the massive increase in cholesterol content in these livers. Ordinarily, an increase in hepatic cholesterol down regulates these mRNAs markedly. Clearly, such down regulation cannot occur when SREBP-1a is synthesized in a truncated form, bypassing the protease that catalyzes the regulated step.

A surprising aspect of these studies was the normal levels of plasma cholesterol and triglycerides in the transgenic mice. Current theory, based on experiments in cultured cells, suggests that increased triglyceride synthesis in liver increases the secretion of triglyceride-carrying VLDL by preventing the premature degradation of its structural protein, apoB (58). It is possible that the transgenic animals are indeed overproducing VLDL, but the hepatic clearance of the lipoprotein has also increased, owing to the increased production of lipoprotein lipase and LDL receptors. Alternatively, overexpression of truncated SREBP-1a may alter lipid synthesis in a fashion that preferentially directs the lipids to storage droplets rather than to the secretory pathway. This question can be answered with

Table III. In Vivo Synthesis of Cholesterol and Fatty Acids in Livers from Wild-type and TgSREBP-1a460 Mice

\begin{tabular}{|c|c|c|c|c|c|}
\hline \multirow{3}{*}{$\begin{array}{l}\text { Genotype of } \\
\text { mice }\end{array}$} & \multirow{3}{*}{$\begin{array}{c}\begin{array}{c}\text { Liver } \\
\text { weight }\end{array} \\
g\end{array}$} & \multicolumn{4}{|c|}{ Incorporation of $\left[{ }^{3} \mathrm{H}\right]$ water into } \\
\hline & & \multicolumn{2}{|c|}{ Digitonin-precipitable sterols } & \multicolumn{2}{|c|}{ Fatty acids } \\
\hline & & $\mu \mathrm{mol} / \mathrm{h}$ per gram & $\mu \mathrm{mol} / \mathrm{h}$ per organ & $\mu \mathrm{mol} / \mathrm{h}$ per gram & umol/h per organ \\
\hline \multicolumn{6}{|l|}{ Wild-type } \\
\hline$(n=4)$ & $0.91 \pm 0.1$ & $1.0 \pm 0.4$ & $0.91 \pm 0.3$ & $2.9 \pm 0.28$ & $2.7 \pm 0.41$ \\
\hline \multicolumn{6}{|c|}{ TgSREBP-1a460 } \\
\hline$(n=6)$ & $2.1 \pm 0.2$ & $5.0 \pm 0.7$ & $10.0 \pm 1.1$ & $74 \pm 7.5$ & $157 \pm 21$ \\
\hline
\end{tabular}

Each value represents the mean \pm SEM of the indicated number of 8 -wk-old littermate mice of the indicated genotype. All mice were fed the low carbohydrate/high protein diet for $2 \mathrm{wk}$ before the experiment. For wild-type mice, 2 males and 2 females were used; for transgenic mice, 3 males and 3 females were used. $\left[{ }^{3} \mathrm{H}\right.$ ] Water was injected intraperitoneally, and one h later the liver was removed for measurement of its content of ${ }^{3} \mathrm{H}-\mathrm{labeled}$ digitonin-precipitable sterols and fatty acids as described in Methods. 
available techniques to measure lipoprotein secretion, and these studies are in progress.

The increase in stearoyl CoA desaturase- 1 in the transgenic mice deserves comment. SREBP-mediated regulation of this enzyme has not been studied previously in cultured fibroblasts. We do not know whether this induction is a direct result of SREBP-1a action, or whether it is triggered secondarily, perhaps as a result of the increase in the synthesis of saturated fatty acids, which are substrates for the enzyme.

The mechanism by which SREBPs regulate $\mathrm{HMG}$ CoA reductase is not yet settled definitively. The endogenous mRNA is markedly increased in tissue culture cells that produce a truncated form of SREBP-2 $(18,19)$. On the other hand, overproduction of SREBP-1a or -2 has only a modest stimulatory effect on transcription of reporter genes driven by sequences from the $5^{\prime}$ flanking region of the HMG CoA reductase gene $(12,13,23)$. Transcription of the HMG CoA reductase gene is complex, with multiple promoters that give rise to multiple transcription initiation sites (59). It is possible that the experiments with reporter genes do not reflect the actual promoter that is being turned on by the SREBPs. The initiation sites of the HMG CoA reductase transcripts in the transgenic mice should be mapped, and additional SRE-1 sequences should be sought.

Considered in isolation, the current data would suggest that cholesterol synthesis and fatty acid synthesis are regulated coordinately in livers. However, earlier experiments on cholesterol feeding in rats found that cholesterol synthesis was suppressed without a decrease in fatty acid synthesis (60). It is likely that alternative transcription factors can activate transcription of the genes involved in fatty acid synthesis when proteolytic activation of the SREBPs has been suppressed. The current experiments were performed in mice fed a low carbohydrate diet in order to induce the PEPCK promoter that drives expression of the SREBP-1a transgene. Such a diet would be expected to suppress fatty acid synthesis, and this may provide a low background against which the stimulating effects of SREBP-1a are more pronounced. It will be important to restudy this issue in transgenic mice expressing truncated SREBP-1a under influence of a promoter that does not require a low carbohydrate diet for induction.

The decrease in adipose tissue mass in the transgenic mice was not expected. Recent studies by Kim and Spiegelman (61) have implicated the nuclear form of SREBP-1 (referred to as ADD1/SREBP1) as a differentiation factor for adipocytes in tissue culture. These studies were performed with SREBP-1c rather than SREBP-1a, and the two forms may have different effects on adipose tissue. Alternatively, the involution of adipose tissue in the transgenic mice may not be a direct response to the SREBP, but rather it may be secondary to the accumulation of triglycerides in the liver. The combined overexpression of lipoprotein lipase and LDL receptors in liver may create a "triglyceride steal" syndrome in which VLDL-triglycerides are preferentially cleared into liver and diverted from adipose tissue. This hypothesis is favored by the progressive nature of the adipose tissue involution. In preliminary experiments we observed that the epididymal fat pads and omental fat appeared normal in transgenic mice in the first 10-12 weeks of life, and they involuted afterwards as the liver enlargement became massive. This issue may be settled when truncated forms of SREBP-1a and SREBP-1c are expressed in transgenic mice with specific promoters that direct expression either toward liver or adipose tissue.
SREBP-1a, which was used in the current studies, differs from SREBP-1c in that it has a longer $\mathrm{NH}_{2}$-terminal acidic transcription activating domain (12). In preliminary experiments, not yet completed, we have found that overexpression of truncated SREBP-1c driven by the PEPCK promoter elevates the mRNAs encoding the cholesterol and fatty acid biosynthetic enzymes to a lesser extent than does truncated SREBP-1a. Whether SREBP-1a or -1c is normally expressed in the liver, and the factors that dictate the balance between the two remain to be explored.

\section{Acknowledgments}

We thank Scott Clark, Shan Maika, and Beth Hinnant for excellent technical assistance and Dr. Laura Woollett for help in the $\left[{ }^{3} \mathrm{H}\right]$ water study.

The study was supported by grants from the National Institutes of Health (HL-20948), the Moss Heart Foundation, the W. M. Keck Foundation, and the Perot Family Foundation. J.D. Horton is the recipient of a Postdoctoral Fellowship for Physicians from the Howard Hughes Medical Institute. I. Shimomura is the recipient of a research fellowship from the Manpei Suzuki Diabetes Foundation of Tokyo, Japan.

\section{References}

1. Gould, R.G. 1951. Lipid metabolism and atherosclerosis. Am. J. Med. 11: 209-227.

2. Gould, R.G., B. Taylor, J.S. Hagerman, I. Warner, and D.J. Campbell. 1953. Cholesterol metabolism. I. Effect of dietary cholesterol on the synthesis of cholesterol in dog tissue in vitro. J. Biol. Chem. 201:519-523.

3. Bucher, N.L.R., P. Overath, and F. Lynen. 1960. $\beta$-Hydroxy- $\beta$-methylglutaryl coenzyme A reductase, cleavage and condensing enzymes in relation to cholesterol formation in rat liver. Biochim. Biophys. Acta. 40:491-501.

4. Siperstein, M.D., and V.M. Fagan. 1966. Feedback control of mevalonate synthesis by dietary cholesterol. J. Biol. Chem. 24l:602-609.

5. Clinkenbeard, K.D., T. Sugiyama, W.D. Reed, and M.D. Lane. 1975. Cytoplasmic 3-hydroxy-3-methylglutaryl coenzyme A synthase from liver: Purification, properties, and role in cholesterol synthesis. J. Biol. Chem. 250:31243135.

6. Clarke, C.F., R.D. Tanaka, K. Svenson, M. Wamsley, A.M. Fogelman, and P.A. Edwards. 1987. Molecular cloning and sequence of a cholesterol-repressible enzyme related to prenyltransferase in the isoprene biosynthetic pathway. Mol. Cell. Biol. 7:3138-3146.

7. Gould, R.G., and E.A. Swyryd. 1966. Sites of control of hepatic cholesterol byosynthesis. J. Lipid Res. 7:698-707.

8. Shechter, I., E. Klinger, M.L. Rucker, R.G. Engstrom, J.A. Spirito, M.A. Islam, B.R. Boettcher, and D.B. Weinstein. 1992. Solubilization, purification, and characterization of a truncated form of rat hepatic squalene synthetase. $J$. Biol. Chem. 267:8628-8635.

9. Horton, J.D., J.A. Cuthbert, and D.K. Spady. 1995. Regulation of hepatic $7 \alpha$-hydroxylase expression and response to dietary cholesterol in the rat and hamster. J. Biol. Chem. 270:5381-5387.

10. Sorci-Thomas, M., M.D. Wilson, F.L. Johnson, D.L. Williams, and L.L. Rudel. 1989. Studies on the expression of genes encoding apolipoproteins B100 and B48 and the low density lipoprotein receptor in nonhuman primates: comparison of dietary fat and cholesterol. J. Biol. Chem. 264:9039-9045.

11. Wang, X., R. Sato, M.S. Brown, X. Hua, and J.L. Goldstein. 1994 SREBP-1, a membrane-bound transcription factor released by sterol-regulated proteolysis. Cell. 77:53-62.

12. Yokoyama, C., X. Wang, M.R. Briggs, A. Admon, J. Wu, X. Hua, J.L. Goldstein, and M.S. Brown. 1993. SREBP-1, a basic helix-loop-helix leucine zipper protein that controls transcription of the LDL receptor gene. Cell. 75: 187-197.

13. Hua, X., C. Yokoyama, J. Wu, M.R. Briggs, M.S. Brown, J.L. Goldstein, and X. Wang. 1993. SREBP-2, a second basic-helix-loop-helix-leucine zipper protein that stimulates transcription by binding to a sterol regulatory element. Proc. Natl. Acad. Sci. USA. 90:11603-11607.

14. Hua, X., J. Sakai, Y.K. Ho, J.L. Goldstein, and M.S. Brown. 1995. Hairpin orientation of sterol regulatory element binding protein-2 in cell membranes as determined by protease protection. J. Biol. Chem. 270:29422-29427.

15. Hua, X., J. Sakai, M.S. Brown, and J.L. Goldstein. 1996. Regulated cleavage of sterol regulatory element binding proteins (SREBPs) requires sequences on both sides of the endoplasmic reticulum membrane. J. Biol. Chem. 271:10379-10384. 
16. Sakai, J., E.A. Duncan, R.B. Rawson, X. Hua, M.S. Brown, and J.L. Goldstein. 1996. Sterol-regulated release of SREBP-2 from cell membranes requires two sequential cleavages, one within a transmembrane segment. Cell. 85 : 1037-1046.

17. Sato, R., J. Yang, X. Wang, M.J. Evans, Y. K. Ho, J.L. Goldstein, and M.S. Brown. 1994. Assignment of the membrane attachment, DNA binding, and transcriptional activation domains of sterol regulatory element binding protein-1 (SREBP-1). J. Biol. Chem. 269:17267-17273.

18. Yang, J., M.S. Brown, Y.K. Ho, and J.L. Goldstein. 1995. Three different rearrangements in a single intron truncate SREBP-2 and produce sterolresistant phenotype in three cell lines. J. Biol. Chem. 270:12152-12161.

19. Yang, J., R. Sato, J.L. Goldstein, and M.S. Brown. 1994. Sterol-resistant transcription in $\mathrm{CHO}$ cells caused by gene rearrangement that truncates SREBP-2. Genes \& Dev. 8:1910-1919.

20. Wang, X., M.R. Briggs, X. Hua, C. Yokoyama, J.L. Goldstein, and M.S. Brown. 1993. Nuclear protein that binds sterol regulatory element of LDL receptor promoter. II. Purification and characterization. J. Biol. Chem. 268:14497-14504.

21. Ericsson, J., S.M. Jackson, B.C. Lee, and P.A. Edwards. 1996. Sterol regulatory element binding protein binds to a cis element in the promoter of the farnesyl diphosphate synthase gene. Proc. Natl. Acad. Sci. USA. 93:945-950.

22. Guan, G., G. Jiang, R.L. Koch, and I. Shechter. 1995. Molecular cloning and functional analysis of the promoter of the human squalene synthase gene. $J$. Biol. Chem. 270:21958-21965.

23. Vallett, S.M., H.B. Sanchez, J.M. Rosenfeld, and T.F. Osborne. 1996. A direct role for sterol regulatory element binding protein in activation of 3-hydroxy3-methylglutaryl coenzyme a reductase gene. J. Biol. Chem. 271:12247-12253.

24. Lopez, J.M., M.K. Bennett, H.B. Sanchez, J.M. Rosenfeld, and T.F. Osborne. 1996. Sterol regulation of acetyl CoA carboxylase: A mechanism for coordinate control of cellular lipid. Proc. Natl. Acad. Sci. USA. 93:1049-1053.

25. Bennett, M.K., J.M. Lopez, H.B. Sanchez, and T.F. Osborne. 1995. Sterol regulation of fatty acid synthase promoter: Coordinate feedback regulation of two major lipid pathways. J. Biol. Chem. 270:25578-25583.

26. Hua, X., J. Wu, J.L. Goldstein, M.S. Brown, and H.H. Hobbs. 1995. Structure of human gene encoding sterol regulatory element binding protein-1 (SREBF1) and localization of SREBF1 and SREBF2 to chromosomes 17p11.2 and 22q13. Genomics. 25:667-673.

27. Sheng, Z., H. Otani, M.S. Brown, and J.L. Goldstein. 1995. Independent regulation of sterol regulatory element binding proteins 1 and 2 in hamster liver. Proc. Natl. Acad. Sci. USA. 92:935-938.

28. Sambrook, J., E.F. Fritsch, and T. Maniatis. 1989. Molecular Cloning: A Laboratory Manual. Cold Spring Harbor Laboratory Press, Cold Spring Harbor, NY.

29. Yokode, M., R.E. Hammer, S. Ishibashi, M.S. Brown, and J.L. Goldstein. 1990. Diet-induced hypercholesterolemia in mice: Prevention by overexpression of LDL receptors. Science (Wash. DC). 250:1273-1275.

30. Bucolo, G., and H. David. 1973. Quantitative determination of serum triglycerides by the use of enzymes. Clin. Chem. 19:476-482.

31. Short, M.K., D.E. Clouthier, I.M. Schaefer, R.E. Hammer, M.A. Magnuson, and E.G. Beale. 1992. Tissue-specific, developmental, hormonal, and dietary regulation of rat phosphoenolpyruvate carboxykinase-human growth hormone fusion genes in transgenic mice. Mol. Cell. Biol. 12:1007-1020.

32. Hofmann, S.L., D.W. Russell, M.S. Brown, J.L. Goldstein, and R.E. Hammer. 1988. Overexpression of low density lipoprotein (LDL) receptor eliminates LDL from plasma in transgenic mice. Science (Wash. DC). 239:12771281.

33. Chen, C.W., and C.A. Thomas, Jr. 1980. Recovery of DNA segments from agarose gels. Anal. Biochem. 101:339-341.

34. Ishibashi, S., M.S. Brown, J.L. Goldstein, R.D. Gerard, R.E. Hammer, and J. Herz. 1993. Hypercholesterolemia in LDL receptor knockout mice and its reversal by adenovirus-mediated gene delivery. J. Clin. Invest. 92:883-893.

35. Ishibashi, S., M. Schwarz, P. Frykman, D.W. Russell, and J. Herz. 1996. Disruption of cholesterol $7 \alpha$-hydroxylase gene in mice. I. Postnatal lethality reversed by bile acid and vitamin supplementation. J. Biol. Chem. 271:1801718023

36. Chen, W.-J., D.A. Andres, J.L. Goldstein, D.W. Russell, and M.S Brown. 1991. cDNA cloning and expression of the peptide-binding $\beta$ subunit of rat p21 ras farnesyltransferase, the counterpart of yeast DPR1/RAM1. Cell. 66: $327-334$

37. Kirchgessner, T.G., K.L. Svenson, A.J. Lusis, and M.C. Schotz. 1987. The sequence of cDNA encoding lipoprotein lipase: a member of a lipase gene family. J. Biol. Chem. 262:8463-8466.

38. Tokunaga, K., H. Taniguchi, K. Yoda, M. Shimizu, and S. Sakiyama. 1986. Nucleotide sequence of a full-length cDNA for mouse cytoskeletal $\beta$-actin
mRNA. Nucleic Acids Res. 14:2829.

39. Beisiegel, U., W.J. Schneider, J.L. Goldstein, R.G.W. Anderson, and M.S. Brown. 1981. Monoclonal antibodies to the low density lipoprotein receptor as probes for study of receptor-mediated endocytosis and the genetics of familial hypercholesterolemia. J. Biol. Chem. 256:11923-11931.

40. Osono, Y., L.A. Woollett, J. Herz, and J.M. Dietschy. 1995. Role of the low density lipoprotein receptor in the flux of cholesterol through the plasma and across the tissues of the mouse. J. Clin. Invest. 95:1124-1132.

41. Dietschy, J.M., and D.K. Spady. 1984. Measurement of rates of cholesterol synthesis using tritiated water. J. Lipid Res 25:1469-1476.

42. Lowenstein, J.M., H. Brunengraber, and M. Wadke. 1975. Measurement of rates of lipogenesis with deuterated and tritiated water. Methods Enzymol. 35B:279-287.

43. Spady, D.K., and J.M. Dietschy. 1983. Sterol synthesis in vivo in 18 tissues of the squirrel monkey, guinea pig, rabbit, hamster, and rat. J. Lipid Res. 24:303-315.

44. Rokosz, L.L., D.A. Boulton, E.A. Butkiewicz, G. Sanyal, M.A. Cueto, P.A. Lachance, and J.D. Hermes. 1994. Human cytoplasmic 3-hydroxy-3-methylglutaryl coenzyme A synthase: Expression, purification, and characterization of recombinant wild-type and Cys ${ }^{129}$ mutant enzymes. Arch. Biochem. Biophys. 312:1-13.

45. Gil, G., J.L. Goldstein, C.A. Slaughter, and M.S. Brown. 1986. Cytoplasmic 3-hydroxy-3-methylglutaryl coenzyme A synthase from the hamster. I. Isolation and sequencing of a full-length cDNA. J. Biol. Chem. 261:3710-3716.

46. Chin, D.J., G. Gil, D.W. Russell, L. Liscum, K.L. Luskey, S.K. Basu, H. Okayama, P. Berg, J.L. Goldstein, and M.S. Brown. 1984. Nucleotide sequence of 3-hydroxy-3-methylglutaryl CoA reductase, a glycoprotein of the endoplasmic reticulum. Nature (Lond.). 308:613-617.

47. Amy, C.M., A. Witkowski, J. Naggert, B. Williams, Z. Randhawa, and S. Smith. 1989. Molecular cloning and sequencing of cDNAs encoding the entire rat fatty acid synthase. Proc. Natl. Acad. Sci. USA. 86:3114-3118.

48. Yuan, Z., W. Liu, and G.G. Hammes. 1988. Molecular cloning and sequencing of DNA complementary to chicken liver fatty acid synthase mRNA. Proc. Natl. Acad. Sci. USA. 85:6328-6331.

49. Ha, J., S. Daniel, I.-S. Kong, C.-K. Park, H.-J. Tae, and K.-H. Kim. 1994. Cloning of human acetyl-CoA carboxylase cDNA. Eur. J. Biochem. 219:297306.

50. Lopez-Casillas, F., D.-H. Bai, X. Luo, I.-S. Kong, M.A. Hermodson, and K.-H. Kim. 1988. Structure of the coding sequence and primary amino acid sequence of acetyl-coenzyme A carboxylase. Proc. Natl. Acad. Sci. USA. 85:57845788 .

51. Inoue, T., T. Osumi, and S. Hata. 1995. Molecular cloning and functional expression of a cDNA for mouse squalene synthase. Biochem. Biophy. Acta. 1260:49-54.

52. Ntambi, J.M., S.A. Buhrow, K.H. Kaestner, R.J. Christy, E. Sibley, T.J. Kelly, Jr., and M.D. Lane. 1988. Differentiation-induced gene expression in 3T3-L1 preadipocytes. J. Biol. Chem. 263:17291-17300.

53. Poncin, J.E., J.A. Martial, and J.E. Gielen. 1984. Cloning and structure analysis of the rat apolipoprotein A-I cDNA. Eur. J. Biochem. 140:493-498.

54. Shoulders, C.C., A.R. Kornblihtt, B.S. Munro, and F.E. Baralle. 1983. Gene structure of human apolipoprotein A1. Nucleic Acids Res. 11:2827-2837.

55. Matsumoto, A., H. Aburatani, Y. Shibasaki, T. Kodama, F. Takaku, and H. Itakura. 1987. Cloning and regulation of rat apolipoprotein B mRNA. Biochem. Biophys. Res. Comm. 142:92-99.

56. Yang, C.-Y., S.-H. Chen, S.H. Gianturco, W.A. Bradley, J.T. Sparrow, M. Tanimura, W.-H. Li, D. A. Sparrow, H. DeLoof, M. Rosseneu, F.-S. Lee, Z.-W. Gu, A. M. Gotto, Jr., and L. Chan. 1986. Sequence, structure, receptorbinding domains and internal repeats of human apolipoprotein B-100. Nature (Lond.). 323:738-742.

57. Rajavashisth, T.B., J.S. Kaptein, K.L. Reue, and A.J. Lusis. 1985. Evolution of apolipoprotein E: Mouse sequence and evidence for an 11-nucleotide ancestral unit. Proc. Natl. Acad. Sci. USA. 82:8085-8089.

58. Ginsberg, H.N. 1995. Synthesis and secretion of apolipoprotein B from cultured liver cells. Curr.Opin. Lipidol. 6:275-280.

59. Reynolds, G.A., J.L. Goldstein, and M.S. Brown. 1985. Multiple mRNAs for 3-hydroxy-3-methylglutaryl coenzyme A reductase determined by multiple transcription initiation sites and intron splicing sites in the $5^{\prime}$ untranslated region. J. Biol. Chem. 260:10369-10377.

60. Siperstein, M.D., and M.J. Guest. 1960. Studies on the site of the feedback control of cholesterol synthesis. J. Clin. Invest. 39:642-652.

61. Kim, J.B., and B.M. Spiegelman. 1996. ADD1/SREBP1 promotes adipocyte differentiation and gene expression linked to fatty acid metabolism. Genes Dev. 10:1096-1107. 